- FINANSE I PRAWO FINANSOWE.

- Journal of Finance and Financial Law

Czerwiec/June 2020 • vol. 2(26): 145-156

https://doi.org/10.18778/2391-6478.2.26.10

\title{
KLASTRY FINANSOWE I AGLOMERACJE FINTECH - CZYNNIKI LOKALIZACYJNE
}

\author{
Michał Włodarczyk \\ Uniwersytet Jagielloński w Krakowie \\ ORCID: https://orcid.org/0000-0001-9913-521X
}

\section{Streszczenie}

Celem tej pracy jest sklasyfikowanie czynników odpowiedzialnych za lokalizację i rozwój klastrów finansowych z wyszczególnieniem aglomeracji FinTech. Sklasyfikowane zostały w tym celu innowacje ich źródła oraz innowacyjność, które odgrywają kluczową rolę w rozwoju FinTechów. Wykazano silne powiązanie pomiędzy wysokim poziomem innowacyjności w skali regionalnej a powstawaniem ośrodków branży FinTech. Dodatkowo proaktywne i nowoczesne podejście do kwestii regulacyjnej było czynnikiem sprzyjającym rozwojowi badanych klastrów finansowych.

Słowa kluczowe: FinTech, bankowość, klastry, kapitał społeczny, innowacyjność.

JEL Class: G21, G28, G23, O31. 


\section{WPROWADZENIE}

W dobie coraz dynamiczniej rozwijającego się sektora nowoczesnych finansów (FinTech), chcąc utrzymać dynamiczny rozwój gospodarczy i społeczny, kładziony jest nacisk na osiąganie wysokiej innowacyjności. Brak jednak regionalnego oraz klastrowego podejścia do finansowych centrów nowych technologii, zwłaszcza w ujęciu Europy. Lepsze zrozumienie czynników lokalizacyjnych pozwoli na wzrost dobrobytu oraz podniesienie konkurencyjności regionów.

Przeprowadzona została analiza poziomu innowacyjności najważniejszych centrów finansowych oraz FinTech w Europie. Poprzedzona została przeglądem literatury oraz klasyfikacją innowacyjności, klastrów oraz sektora FinTech. Praca kończy się podsumowaniem i rekomendacjami do dalszych badań.

Wskaźniki determinujące innowacyjne klastry i regiony na terenie Europy charakteryzują się tymi samymi czynnikami, m.in. wysoce wykwalifikowaną kadrą, dużym odsetkiem patentów, wysokimi nakładami na działalność badawczo-rozwojową oraz nowoczesnym aparatem regulacyjnym. Widoczna jest różnica pomiędzy liderami innowacji na kontynencie a krajami posiadającymi największe aglomeracje FinTech i centra finansowe. Głównym powodem tego stanu jest koncentracja potencjału innowacyjnego najczęściej w stolicy, co umożliwia wymianę know-how, dyfuzję innowacji oraz wyższą konkurencyjność, zarówno wewnętrzną, jak i globalną.

\section{INNOWACJE ORAZ POJĘCIE INNOWACYJNOŚCI}

Innowacjami określa się jako nowe kombinacje środków produkcji, które wprowadzone na rynek powodują zburzenie dotychczasowych struktur i stymulowanie rozwoju [Glapiński 2012: 4-6]. Termin wprowadzony przez Josepha Shumpetera w 1883 r. określał w ten sposób wprowadzenie nowego produktu, metody, rynku zbytu, surowców, materiałów lub formy organizacyjnej [Marciniak 2010: 16]. Dwiema najistotniejszymi cechami innowacji są: nowość oraz realne wprowadzenie na rynek, tak by rozwiązanie mogło wpływać na konkurencję i zmienić dotychczasowe status quo.

W XX w. pojęcie to zostało doprecyzowane przez Petera Druckera. Jego definicja innowacji zakłada, że jest to narzędzie, które w rękach przedsiębiorczej osoby pozwala na rozwój i tworzenie wartości i dobrobytu [Drucker 1992: 39 -40]. Peter Drucker zdefiniował także pojęcie innowacyjności, jako systematyczne, zorganizowane i celowe poszukiwanie zmian i analiza okazji do społecznej lub gospodarczej innowacji, którą by ta zmiana spowodowała.

W XXI w. Richard Florida ściśle powiązał innowacyjność z szansami do rozwoju. Według niego głównym motorem stojącym za współczesnym rozwojem 
gospodarczym, jak i innowacjami jest kreatywność. W jej wyniku osiągany jest sukces i dobrobyt mieszkańców regionów, w których duży nacisk kładziony jest na badania, nowe technologie i twórcze zawody. Opisał on tzw. klasę kreatywna, budującą gospodarkę opartą na wiedzy. Zalicza do niej osoby z wyższym wykształceniem, umiejętnością analizowania i rozwiązywania problemów i właśnie kreatywne [Klasa kreatywna..., dostęp 20.06.2019].

Do źródeł innowacji można zaliczyć te, wynikające z rozwoju naukowo-technicznego (podażowe) oraz potrzeb rynkowych (popytowe). Do źródeł popytowych można zaliczyć m.in. potrzeby klientów, przedsiębiorstw i agencji rządowych, świadomość ekologiczną (ochrona środowiska naturalnego), potrzebę bezpieczeństwa (w miejscu pracy, życiu prywatnym oraz obronności kraju). Do źródeł popytowych również zalicza się gusta konsumentów i ich zmiany, przewidywane fluktuacje popytu i dochodów oraz konkurencję międzynarodową. Źródłami podażowymi określa się odkrycia pochodzące od naukowców. Współczesne badania ukazują, że podażowe źródła innowacji stanowią jedynie od 10 do 40\% wszystkich innowacji [Marciniak 2000: 42-45].

Istotną kwestią w zakresie innowacji są bariery stojące na drodze do ich rozprzestrzeniania. Do finansowych, zwanych też rynkowymi lub kosztowymi, można wyróżnić: kwestie konkurencji ze strony globalnych korporacji, spadku popytu na towary i możliwe kryzysy lub spowolnienia gospodarcze, problemy z dostępem do kapitału, niską płynność finansową i niską ściągalność należności. Do prawnych można zaliczyć: niejasność i brak stabilnych regulacji podatkowych i prawnych, wysokie obciążenia finansowe oraz braki instytucjonalne (biurokracja, utrudnione pozyskiwanie informacji rynkowych oraz brak informacji co do możliwej współpracy i kooperacji z innymi firmami) [Piotrowska 2013: 129-130].

Istotnym zagadnieniem, oprócz zdefiniowania i sklasyfikowania innowacji i innowacyjności, jest sposób mierzenia ich poziomu. W Europie stosuje się Europejski Ranking Innowacyjności (European Innovation Scoreboard), Regionalny Ranking Innowacyjności oraz Community Innovation Survey. Przygotowywane są one przez Eurostat i OECD.

CIS jest programem badań statystycznych, który za pośrednictwem krajowych urzędów statystycznych oraz ministerstw zbiera dane o podmiotach (przedsiębiorstwach przemysłowych i usługowych o więcej niż 9 pracownikach). Zbiera on dane na temat [Community Innovation Survey..., dostęp 14.06.2019]:

- liczby wprowadzonych innowacji w ciągu ostatnich 3 lat,

- wielkości nakładów na działalność badawczo-rozwojową,

- wpływu innowacji na wyniki przedsiębiorstwa,

- źródeł informacji w ujęciu innowacji,

- celów działalności innowacyjnej,

- współpracy z innymi podmiotami podczas prowadzenia działalności innowacyjnej, 
- metod ochrony innowacji przez konkurencją i dyfuzją innowacji,

- przeszkód jakie napotkano.

Dane zebrane przez CIS są używane do tworzenia Europejskiego i Regionalnego Rankingu Innowacyjności. Uzupełnia się je o dane pochodzące z Europejskiego Urzędu Patentowego oraz Urzędu Harmonizacji w ramach Rynku Wewnętrznego. Wyniki tych rankingów są stosowane w polityce gospodarczej i naukowo-technicznej dla całej wspólnoty. W EIS wykorzystywanych jest 27 czynników zaś w wersji regionalnej (RIS) - 17 . Wynika to z metody zbierania danych.

Czynniki są agregowane w 4 grupach [European Innovation Scoreboard. Methodology Report, 2019: 4-11]:

- warunki ramowe (framework resources) - w tej grupie znajdują się kwestie zasobów ludzkich, stopień umiędzynarodowienia systemu badawczego oraz środowisko przyjazne innowacjom,

- inwestycje (investments) - są to wydatki na działalność badawczo-rozwojową firm prywatnych i państwowych,

- działalność innowacyjna (innovative activities) - innowatorzy, powiązania i własność intelektualna,

- wpływ (impact) - zatrudnienie w zawodach wymagających wiedzy oraz innowacyjnych sektorach, wysoko zaawansowane produkty kierowane na eksport oraz sprzedaż innowacyjnych produktów.

Na bazie wyników kategoryzuje się regiony lub kraje w jedną z czterech grup:

- liderzy innowacji,

- silni innowatorzy,

- umiarkowani innowatorzy,

- skromni innowatorzy.

\section{SEKTOR FINTECH}

W wyniku rozwoju technologicznego branża finansowa, a szczególnie bankowa, przeszła ewolucję. W wyniku komputeryzacji możliwe było cyfrowe obsługiwanie transakcji giełdowych, a następnie cyfrowe funkcjonowanie podmiotów finansowych. W latach $90 . \mathrm{XX}$ w. pojawiła się bankowość telefoniczna i internetowa, by na przełomie pierwszej i drugiej dekady XXI w. przekształcić się w wersję mobilną. W tym okresie powstawać zaczął dynamicznie rozwijający się nowy sektor nazwany FinTech (od połączenia słów „finance” i „technology”).

FinTech uznaje się za sektor wysoce innowacyjny, ponieważ w jego założeniach głównym orężem w walce konkurencyjnej są najnowsze zdobycze technologiczne, takie jak [Redrawing the lines..., 2017: 9]:

- rozwój rozwiązań na urządzenia mobilne,

- zaawansowana analityka danych (Big Data), 
- rozwój sztucznej inteligencji (algorytmy, sieci neuronowe, uczenie maszynowe),

- cyberbezpieczeństwo,

- robotyzacja i automatyzacja procesów,

- biometria oraz identyfikacja tożsamości,

- blockchain.

Wykorzystanie zaawansowanych rozwiązań technicznych oraz ciągła praca nad rozwijaniem i dopracowywaniem ich wymaga najwyższej klasy specjalistów z zakresu finansów, ekonometrii, informatyki, robotyki.

Tabela 1. Klasyfikacja zakresu przedmiotowego działalności sektora FinTech

\begin{tabular}{|c|c|c|c|}
\hline $\begin{array}{c}\text { Usługi } \\
\text { depozytowo-kredytowe }\end{array}$ & \multicolumn{2}{|c|}{$\begin{array}{c}\text { Płatności, usługi rozliczenia } \\
\text { i rozrachunku }\end{array}$} & $\begin{array}{c}\text { Usługi zarząazania } \\
\text { inwestycjami }\end{array}$ \\
\hline Crowdfunding & Detaliczne & Hurtowe & $\begin{array}{c}\text { Handel wysokich } \\
\text { częstotliwości }\end{array}$ \\
\hline Platformy pożyczkowe & Mobilne portfele & $\begin{array}{c}\text { Alternatywne sieci } \\
\text { przekazów } \\
\text { pieniężnych }\end{array}$ & Kopiowanie transakcji \\
\hline Bankowość mobilna & $\begin{array}{c}\text { Płatności } \\
\text { peer-to-peer }\end{array}$ & $\begin{array}{c}\text { Usługi walutowe } \\
\text { dla firm }\end{array}$ & $\begin{array}{c}\text { Internetowe platformy } \\
\text { transakcyjne }\end{array}$ \\
\hline Credit scoring & Kryptowaluty & $\begin{array}{c}\text { Platformy obrotu } \\
\text { kryptowalutami }\end{array}$ & Robodoradztwo \\
\hline
\end{tabular}

Źródło: Harasim i Mitręga-Niestrój, 2018: 174.

Przedstawiony w tabeli 1 podział obszarów zainteresowań przedsiębiorstw sektora FinTech ilustruje, że prowadzą one pracę nad unowocześnieniem praktycznie wszystkich dziedzin finansów, od detalicznych przez inwestycyjne po automatyzację samych procesów wewnętrznych. Można założyć, że powody lokalizacji firmy FinTechowych mogą być przez to zbliżone do już istniejących centrów finansowych oraz informatycznych na świecie, gdyż potrzebują one podobnych zasobów ludzkich, prawnych oraz finansowych co te dwie branże.

\section{KLASTRY FINANSOWE}

Stworzona przez Michaela Portera koncepcja klastra wynika z koncentracji i kooperacji właśnie. Według niego, klastrem nazywa się geograficzne skupisko przedsiębiorstw ze sobą wzajemnie powiązanych, wyspecjalizowanych dostawców, jednostek świadczących usługi oraz firm z pokrewnych sektorów i związanych z nimi instytucji oraz uczelni wyższych. Wymienione podmioty w niektórych dziedzinach konkurują ze sobą (co jest typowe dla gospodarki rynkowej), jednak w pewnych dziedzinach ze sobą współpracują [Kowalski 2011: 80-81]. 
Owa współpraca pozwala na maksymalizację zwrotu z nakładów na badania i rozwój, lepszą wymianę handlową oraz usprawnienie produkcji dzięki przepływowi know-how, pracowników i technologii [Klaster ..., dostęp 20.06.2019].

W przypadku klastrów skupiających się na usługach finansowych, najważniejszym czynnikiem jest dostęp do zasobnego rynku pracy z wysoko wykwalifikowaną siłą roboczą. Poszukiwana jest znajomość rynku finansowego oraz doświadczenie potencjalnych pracowników. To implikuje, by lokalizacja takiego klastra znajdowała się blisko miast i aglomeracji, które już posiadają centrale banków, giełd papierów wartościowych i instytucji finansowych (które dysponują już doświadczonymi specjalistami) oraz by występowały finansowe i ekonomiczne uczelnie wyższe, które kształcić będą kolejne pokolenia specjalistów z branży finansowej.

Istotnym faktem jest to, że występuje zjawisko braku chęci zmiany miejsca zamieszkania wśród specjalistów z dużym stażem i dorobkiem. Zatem korzystniejsza jest koncentracja aniżeli rozproszenie w kwestii efektywności tworzenia innowacji. Niezależnie czy klaster skupia się na inwestycjach, bankowości, księgowości czy doradztwie, konieczne jest innowacyjne środowisko, zarówno naukowe, jak i biznesowe. Widoczne jest zatem bliskie spokrewnienie wymogów klastrów high-tech i nowoczesnych finansów [Financial services clustering..., 2003: 24-25].

Możliwe jest powiązanie lokalizacji aglomeracji FinTech i klastrów finansowych z nowoczesnym ośrodkiem pełniącym już istotną rolę gospodarczą. Od 2007 r. China Development Institute (Shenzen) oraz Z/Yen Partners (Londyn) tworzą, bazując na ponad 100 czynnikach, indeks konkurencyjności centrów finansowych - Global Financial Centres Index.

Wykonywanych jest ponad 29000 prób z kwestionariuszy oraz korzystają one z danych Banku Światowego oraz OECD. Na 100 największych centrów finansowych 38 jest $z$ Europy. W globalnym rozrachunku widać silną pozycję USA i Kanady, Chin, Indii oraz Zachodniej Europy (głównie Francji, Wielkiej Brytanii, Niemiec i północnych Włoszech). Pozostałe kraje europejskie posiadają w tym zestawieniu co najwyżej swoją stolicę (m.in. Madryt, Praga, Wiedeń czy Warszawa). Niekwestionowanym liderem w Europie jest Londyn (2 miejsce na świecie) [GFCI 25 Report 2019: 39].

\section{KLASTRY FINANSOWE I FINTECH A INNOWACYJNOŚĆ}

Aglomeracje skupiające firmy FinTech można zaliczyć do klastrów bazujących na wiedzy. Wynikające wprost $\mathrm{z}$ definicji, a także z nazwy, powiązanie tego sektora $\mathrm{z}$ technologią pozwala zaklasyfikować je w nomenklaturze European Cluster Observatory do „digital-based industries”. 
W ujęciu geograficznym widoczne jest skupienie takowych klastrów w 6 miejscach Europy [European Cluster Trends 2015: 29-30]:

- Holandia Północna (Holandia),

- Düsseldorf (Niemcy),

- Île de France (Francja),

- Berlin (Niemcy),

- Londyn Wewnętrzny (Wielka Brytania),

- Górna Bawaria (Niemcy).

Rozwój sektora innowacyjnego oraz technologicznego, w tym FinTech, w tych regionach jest stymulowany dostępnymi tam czynnikami, takimi jak: obecność dużych firm, siedziby dużych banków, inkubatory i akceleratory dla start-upów i ułatwienia prawno-fiskalne. W połączeniu $\mathrm{z}$ tym, iż regiony te są silnie rozwinięte $\mathrm{w}$ gałęziach, takich jak motoryzacja czy informatyka, tworzy się swoisty mikroklimat zachęcający nie tylko do przedsiębiorczości, ale i ściągania kolejnych specjalistów do regionu, przez co widoczny jest efekt kuli śnieżnej [Gazel i Schwienbacher 2018: 8-10].

Skupiska tworzące aglomeracje FinTech przypominają zasadami działania powstawanie centrów finansowych. Bardzo często powstają w miastach, które status takiego centrum już posiadają. W międzynarodowych centrach finansowych (IFC) koncentracja umożliwia wymianę pomiędzy firmami i transgraniczne działalności tychże firm (cross-border business).

Tworzeniu i rozwojowi IFC służą przede wszystkim ramy prawne. Wymogi prawne, kwestie ochrony praw własności i patentów, polityka wspierania biznesu, zaufanie i niska korupcja były w przeszłości głównymi czynnikami lokalizacyjnymi. Samo w sobie proste, szybko dostosowujące się do zmian prawo z zakresu działalności biznesowej, takie jak anglosaskie common law, oparte na precedensach, ujawniało od dekad korelację z szybkim rozwojem gospodarczym i rynków kapitałowych. Prawo to, w połączeniu z anglosaskim, ukierunkowanym na rynki systemem finansowym, dawało prowadzenie USA i Wielkiej Brytanii w koncertowaniu finansów.

Wśród czynników determinujących tworzenie się IFC jest obecność giełdy, ważna rola administracyjna miasta (np. stolica), wysoce wykwalifikowana i elastyczna siła robocza, otwarty rynek (Terms of Trade), wysoka jakość infrastruktury (lotniska międzynarodowe, szybka kolej, autostrady, szerokopasmowy Internet, rozbudowana komunikacja miejska) oraz miejsca pracy na najwyższym poziomie [Wójcik i in. 2018: 1-7]. 
Tabela 2. Największe centra finansowe w Unii Europejskiej i ich innowacyjność

\begin{tabular}{|c|c|c|c|}
\hline Kraj & $\begin{array}{l}\text { Liczba ośrodków } \\
\text { na liście } \\
\text { GFCI } 25\end{array}$ & $\begin{array}{l}\text { Innowacyjność kraju } \\
\text { wg EIS }\end{array}$ & $\begin{array}{c}\text { Innowacyjność regionów } \\
\text { wg RIS }\end{array}$ \\
\hline $\begin{array}{c}\text { Wielka } \\
\text { Brytania }\end{array}$ & $\begin{array}{c}\text { Londyn, } \\
\text { Edynburg, } \\
\text { Glasgow, } \\
\text { Wyspa Man }\end{array}$ & Silny innowator & $\begin{array}{l}\text { Liderzy innowacji i silni } \\
\text { innowatorzy }\end{array}$ \\
\hline Niemcy & $\begin{array}{l}\text { Frankfurt, } \\
\text { Monachium, } \\
\text { Stuttgart, } \\
\text { Hamburg, }\end{array}$ & Silny innowator & $\begin{array}{l}\text { Liderzy innowacji i silni } \\
\text { innowatorzy }\end{array}$ \\
\hline Francja & Paryż & Silny innowator & Silny innowator \\
\hline Luksemburg & Luksemburg & Silny innowator & Silny innowator \\
\hline Hiszpania & Madryt & Umiarkowany innowator & Umiarkowany innowator \\
\hline Irlandia & Dublin & Silny innowator & Silny innowator \\
\hline Holandia & Amsterdam & Lider innowacji & Lider innowacji \\
\hline Austria & Wiedeń & Silny innowator & Silny innowator \\
\hline Włochy & Mediolan, Rzym & Umiarkowany innowator & Umiarkowany innowator \\
\hline Belgia & Bruksela & Silny innowator & Silny innowator \\
\hline Szwecja & Sztokholm & Lider innowacji & Lider innowacji \\
\hline Portugalia & Lizbona & Umiarkowany innowator & Silny innowator \\
\hline Czechy & Praga & Umiarkowany innowator & Silny innowator \\
\hline Polska & Warszawa & Umiarkowany innowator & Umiarkowany innowator \\
\hline Węgry & Budapeszt & Umiarkowany innowator & Umiarkowany innowator \\
\hline Finlandia & Helsinki & Lider innowacji & Lider innowacji \\
\hline Dania & Kopenhaga & Lider innowacji & Lider innowacji \\
\hline Lotwa & Ryga & Umiarkowany innowator & Umiarkowany innowator \\
\hline Bułgaria & Sofia & Skromny innowator & Umiarkowany innowator \\
\hline Malta & Valetta & Umiarkowany innowator & Umiarkowany innowator \\
\hline Cypr & Nikozja & Umiarkowany innowator & Umiarkowany innowator \\
\hline Estonia & Tallin & Silny innowator & Silny innowator \\
\hline
\end{tabular}

Źródło: GFCI 25 Report 2019: 5-6; European Innovation Scoreboard 2019; Regional Innovation Scoreboard 2019.

W kontekście wymienionych czynników oraz opisanych źródeł innowacyjności, można pokusić się o próbę połączenia tych zjawisk. W tabeli 2 znajdują się wszystkie europejskie IFC z listy 100 największych centrów finansowych. Pogrupowane są one wedle krajów, w których się znajdują. Do każdego kraju 
przyporządkowane są stopnie innowacyjności wedle EIS oraz innowacyjność regionów, w których dane ośrodki się znajdują (wg RIS).

Widoczny jest podział na „nową” i „starą” Unię, gdzie wśród krajów Europy Środkowo-Wschodniej występują jedynie stolice, które dodatkowo znajdują się w mało i umiarkowanie innowacyjnych regionach i państwach. „Rdzeniem” europejskiej innowacji oraz finansów są Niemcy, Wielka Brytania, Francja, Holandia, Hiszpania i Irlandia.

Kraje skandynawskie, pomimo wysokich lokat w rankingach innowacyjności, nie posiadają swoich przedstawicieli w ścisłej czołówce. $\mathrm{W}$ ich przypadku działalność badawcza ukierunkowana jest częściej na nauki przyrodnicze oraz techniczne aniżeli finanse. W przypadku Luksemburgu i Irlandii rola finansowa jest stymulowana korzystnymi przepisami i niskimi podatkami (oba te kraje stanowią raje podatkowe). Francuski Paryż oraz hiszpański Madryt pokazują podobną tendencję, co kraje mniej innowacyjne, tj. skupienie przeważającej ilości nakładów na badania, kapitału oraz specjalistów w stolicy, co naturalnie podnosi jego znaczenie na arenie (potencjał kraju kumulowany jest w stolicy).

Najciekawszymi przykładami są Niemcy oraz Wielka Brytania, które znane są powszechnie z silnej i innowacyjnej gospodarki. W ich przypadku, pomimo niższej niż w Skandynawii średniej innowacyjności w skali kraju, istnieje sieć silnych aglomeracji finansowych. Wokół nich tworzą się klastry, co powoduje, że oprócz wymiany wiedzy wewnątrz klastra, możliwa jest współpraca pomiędzy krajowymi klastrami (pomaga w tym wydajny narodowy system wspierania innowacyjności).

W kwestii centrów FinTech, w globalnym rozrachunku widoczne są głównie ośrodki europejskie, chińskie i amerykańskie oraz pojedyncze reprezentacje w postaci Singapuru, Tokio, Tel Avivu, Sydney i Toronto. Według Global Financial Centres Index, mierzącym atrakcyjność, konkurencyjność oraz regulacje, największymi europejskimi aglomeracjami FinTech są: Londyn, Frankfurt, Paryż, Berlin, Amsterdam i Dublin [GFCI 25 Report 2019: 39].

Europejski rynek FinTech w samym 2018 r. był miejscem 536 transakcji na kwotę 34,2 miliarda dolarów. W ujęciu klastrów i aglomeracji FinTech istotna jest lokalizacja największych transakcji. Na 10 największych inwestycji, 4 były na terenie Wielkiej Brytanii, 3 w Szwecji, 2 w Rosji oraz 1 w Danii [The Pulse of Fintech, 2019: 56].

W czołówce rankingów innowacyjności oraz internacjonalizacji finansów, od lat niezmiennie pojawia się Londyn. W zestawieniach aglomeracji FinTech od lat znajduje się w gronie nie regionalnych, a globalnych liderów. Czynnikami stojącymi za wysokimi wynikami są [The Future of Finance is Emerging..., 2018: 21 $-22]$ :

- światowy rynek finansowy - bez wątpienia londyńska giełda oraz sektor finansowo-bankowy daje przewagę nad innymi miastami Europy i świata. Duże 
instytucje, jak HSBC, Lloyds i Barclays oraz dynamicznie rozwijające się Neobanki, jak Revolut czy Monzo, umacniają pozycję oraz utrzymują rozwój klastra, zaś łatwość pozyskania inwestora zachęca przedsiębiorców do lokowania swoich firm właśnie tam;

- najlepsze uczelnie - wg rankingu wszechstronności, londyńskie uczelnie zajmują 2 miejsce na świecie. Zapewnia to napływ wysoko wykwalifikowanych pracowników oraz dostęp do innowacji finansowych tworzonych w instytutach badawczych na uniwersytetach;

- pionier w regulacji sektora FinTech - Wielka Brytania już w 2013 r. utworzyła Financial Conduct Authority, którego zadaniem jest regulacja rynku płatności i FinTech. Tworzone są piaskownice regulacyjne, a metody używane przez FCA stosowane są często na całym świecie;

- wynikająca z postępowości regulatora zachęta oraz możliwości współpracy sektora FinTech z tradycyjnymi bankami, przez co obie strony mogą zyskać. Dodatkowo rozwój otwartej bankowości (open banking) sprzyja kumulacji specjalistów od sztucznej inteligencji, robotyki i Big Data, gdyż w powstających think tankach możliwe jest tworzenie nowych rozwiązań.

\section{PODSUMOWANIE}

Dzięki rozwojowi nowych technologii, współcześnie - jak nigdy dotąd - wysoka jest innowacyjność na świecie. Zmienia ona status quo w kolejnych sektorach i branżach w gospodarce, nie omijając sektora finansowego. Od przeszło 20 lat rozwija się i powiększa nowy sektor, oferujący rozwiązania technologiczne dzięki wykorzystywaniu najnowszych zdobyczy technologicznych, który zyskał nazwę FinTech.

Podobnie, jak w ogólnym spojrzeniu na gospodarkę, widoczne jest tworzenie się wyspecjalizowanych regionów, gdzie poza wspólnym lub pokrewnym obszarem działalności, widoczna jest współpraca podmiotów, które w domyśle powinny ze sobą konkurować. Tworzące się klastry umożliwiają nawet niewielkim firmom dynamiczny rozwój i siłę przebicia na rynku oraz - co najważniejsze - maksymalizację nakładów na działalność badawczo-rozwojową.

Czynniki będące źródłami innowacyjności regionów oraz krajów determinują lokalizację oraz rozwój już istniejących klastrów finansowych w Europie. Widoczna jest różnica pomiędzy krajami o średniej innowacyjności (stolica w roli jedynego centrum finansowego), krajami skandynawskimi (liderzy w innowacyjności, jednak bez kilku głównych ośrodków w skali globalnej) i najważniejszymi ośrodkami finansowymi i FinTech (jak Londyn czy Frankfurt).

Na terenie Europy i Unii Europejskiej niewątpliwym rekordzistą jest Londyn, który skupia duży udział nie tylko europejskiego, ale i światowego sektora 
FinTech. Jest on pionierem innowacyjnej regulacji rynków (FCA) oraz świetnie wykorzystuje swoje zasoby, by podtrzymywać dynamiczny rozwój.

Rekomendacją do dalszych badań jest analiza poszczególnych czynników wykorzystywanych przez GFCI oraz Global FinTech Hub i porównanie ich z innowacyjnością, mierzoną metodą Eurostatu i OECD. Wyniki takie mogą rzucić nowe światło na czynniki kluczowe do rozwoju aglomeracji FinTech, które mogą zostać wykorzystane przez mniejsze ośrodki, jak Warszawa czy Praga.

\section{BIBLIOGRAFIA}

Community Innovation Survey, [w:] Stownik Innowacji-Leksykon haset, http://www.pi.gov.pl/parp/chapter_96055.asp?soid=8AB71371365B49A9B7CC765EA70F8CC5 [dostęp 14.06.2019].

Drucker P., 1992, Innowacja i przedsiębiorczość. Praktyka i zasady, PWE, Warszawa.

European Cluster Trends, 2015, European Cluster Observatory, Komisja Europejska.

European Innovation Scoreboard, 2019, European Commission, Joint Research Centre, Competence Centre on Composite Indicators and Scoreboards.

European Innovation Scoreboard. Methodology Report, 2019, European Commission, Joint Research Centre, Competence Centre on Composite Indicators and Scoreboards.

Financial services clustering and its significance for London, 2003, Corporation of London, Londyn.

Gazel M., Schwienbacher A., 2018, Enterpreneurial Fintech Clusters, „SSRN Electronic Journal”, $\mathrm{nr} 1$.

GFCI 25 Report, 2019, CDI \& Z/Yen.

Glapiński A., 2012, Schumpeterowska teoria przedsiębiorcy, czyli skąd się bierze pies, „Konsumpcja i rozwój", nr 1(2).

Harasim J., Mitręga-Niestrój K., 2018, Fintech - Dylematy definicyjne i determinanty rozwoju, „Prace Naukowe Uniwersytetu Ekonomicznego we Wrocławiu”, nr 531.

Klasa kreatywna, [w:] Stownik Innowacji - Leksykon hasel, http://www.pi.gov.pl/PARP/chapter_96055.asp?soid=9FC93091B07344FCBC36C28830C958F8 [dostęp 20.06.2019].

Klaster, [w:] Stownik Innowacji - Leksykon haset, https://www.pi.gov.pl/klastry/chapter_95882.asp [dostęp 20.06.2019].

Kowalski A.M., 2011, Europejskie inicjatywy na rzecz zwiększania innowacyjności i konkurencyjności gospodarki przez internacjonalizację klastrów, „Studia Europejskie / Centrum Europejskie Uniwersytetu Warszawskiego", nr 1.

Marciniak S., 2000, Innowacje i rozwój gospodarczy, wyd. III, Kolegium Nauk Społecznych i Administracyjnych Politechniki Warszawskiej, Warszawa.

Marciniak S., 2010, Innowacyjność i konkurencyjność gospodarki, Wydawnictwo C.H. Beck, Warszawa.

Piotrowska J., 2013, Stymulanty i bariery działalności innowacyjnej w kontekście rozwoju przedsiębiorstw w Polsce, ,Zeszyty Naukowe Uniwersytetu Szczecińskiego. Studia i Prace Wydziału Nauk Ekonomicznych i Zarządzania", nr 32, tom 2.

Redrawing the lines: FinTech's growing influence on Financial Services, 2017, Global FinTech Report 2017, PwC.

Regional Innovation Scoreboard, 2019, European Commission, Joint Research Centre, Competence Centre on Composite Indicators and Scoreboards.

The Future of Finance is Emerging: New Hubs, New Landscapes, Global FinTech Hub Report, 2018, Cambridge Center for Anternative Finance. 
The Pulse of Fintech, 2019, Biannual global analysis of investment in fintech, KPMG.

Wójcik D., Knight E., Pazitka V., 2018, What turns cities into internationasl financial centres?, „Journal of Economic Geography”, no. 18.

FINANCIAL CLUSTERS AND FINTECH AGGLOMERATIONS - LOCATION FACTORS

\begin{abstract}
The purpose of this work is to classify the factors responsible for the location and development of financial clusters, detailing the FinTech agglomeration. For this purpose they have been classified innovations, their sources and innovativeness, which play a key role in the development of FinTechs. A strong link has been demonstrated between the high level of innovation on a regional scale and the creation of FinTech industry centers. In addition, a proactive and modern approach to the regulatory issue was a factor conducive to the development of the studied financial clusters.
\end{abstract}

Keywords: FinTech, banking, clusters, social capital, innovation. 